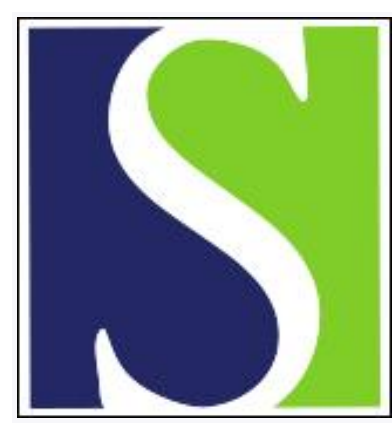

Scand J Work Environ Health 1983;9(3):241-246

https://doi.org/10.5271/sjweh.2414

Issue date: Jun 1983

Increased frequency of lymphocyte micronuclei in workers producing reinforced polyester resin with low exposure to styrene.

by Hogstedt B, Akesson B, Axell K, Gullberg B, Mitelman F, Pero RW, Skerfving $\mathrm{S}$, Welinder $\mathrm{H}$

This article in PubMed: www.ncbi.nlm.nih.gov/pubmed/6612264

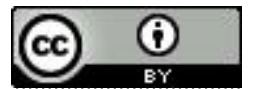




\title{
Increased frequency of lymphocyte micronuclei in workers producing reinforced polyester resin with low exposure to styrene
}

\begin{abstract}
by Benkt Högstedt, MD, 1234 Bengt Åkesson, BSc, ${ }^{2}$ Kaj Axell, MD, ${ }^{5}$ Bo Gullberg, $B S c,{ }^{2}$ Felix Mitelman, MD, ${ }^{3}$ Ronald W Pero, PhD, ${ }^{6}$ Staffan Skerfving, $\mathrm{MD},{ }^{2}$ Hans Welinder, MSc ${ }^{2}$

HÖGSTEDT B, AKESSON B, AXELL K, GULLBERG B, MITELMAN F, PERO RW, SKERFVING S, WELINDER $\mathrm{H}$. Increased frequency of lymphocyte micronuclei in workers producing reinforced polyester resin with low exposure to styrene. Scand $j$ work environ health 9 (1983) 241-246. A new micronucleus method based on the analysis of lymphocytes with preserved cytoplasm revealed an increased frequency of micronuclei in 38 workers employed in a plant producing styrene-modified polyester resin as compared to the frequency in 20 referents ( $5.9 \mathrm{vs} 3.6 \%$ ). The time-weighted average of the styrene concentration in the workroom air varied between 1 and $36 \mathrm{ppm}$ (mean $13 \mathrm{ppm}$ ) during the last year and correlated well to low urinary levels of mandelic acid, which ranged from 9 to $316 \mathrm{mg} / \mathrm{g}$ of creatinine (mean $65 \mathrm{mg} / \mathrm{g}$ of creatinine).
\end{abstract}

Key terms: micronucleus analysis,

After the mutagenic and carcinogenic properties of vinyl chloride were revealed, interest was focused on other related chemical compounds such as styrene. By now it is known that styrene and its metabolite styrene-7,8,-oxide have mutagenic and/or carcinogenic effects in different test systems. For a review see the report of Norppa (9).

The most important source of occupational exposure to styrene is the production of styrene-modified fiberglass reinforced unsaturated polyester resin. Earlier

1 Department of Occupational Medicine, Central Hospital, Halmstad, Sweden.

2 Department of Occupational Medicine, University Hospital, Lund, Sweden.

3 Department of Clinical Genetics, University Hospital, Lund, Sweden.

4 Institute of Environmental Health, University of Lund, Sweden.

5 Occupational Health Center, Ljungby, Sweden.

6 Wallenberg Laboratory, Biochemical and Genetic Ecotoxicology, Lund, Sweden.

Reprint requests to: Dr B Högstedt, Department of Occupational Medicine, Central Hospital, S-301 85 Halmstad, Sweden. studies on workers occupationally exposed to styrene have shown increased frequencies of chromosome damage at exposure levels of $25-300 \mathrm{ppm}$ as the 8-h time-weighted average $(1,3,4,7)$. In Sweden the exposure levels have decreased considerably during the last few years.

Micronuclei are thought to be indicators of either chromosome breaking events or failure of the spindle apparatus. In the investigations of Countryman \& Heddle (2), Linnainmaa et al (6), Meretoja et al (7) and Norman et al (8) micronuclei in cultured lymphocytes have been analyzed in hypotonically treated cells. Since this treatment destroys the cytoplasm, the method seems to have certain cytological disadvantages.

The aim of the present study was to investigate the effects of styrene at low levels of exposure by a new method for analyzing micronuclei in lymphocytes; the cell cytoplasm was preserved in order to increase the precision of determination. The methodological aspects of the new method will be discussed in a future publication (Högstedt, to be published). 


\section{Material and methods}

\section{Subjects}

The styrene-exposed group consisted of 38 men working in a factory producing fiberglass reinforced polyester resin (table 1). The referents were 20 male workers from a mechanical industry in the same town. The factory in which the exposed subjects worked manufactured unsaturated polyester from propylene and/or ethylene glycol with maleic and/or phthalic anhydride. Hydroquinone was used as an inhibitor. This alkyd resin was mixed with styrene (70/30 weight/weight). In the factory it was cured by different peroxides (cyclohexanone or methyl ethyl ketone peroxide and/or benzoyl peroxide). The curing process was accelerated by the

Table 1. Summary of data on the styrene-exposed subjects and the referents.

\begin{tabular}{|c|c|c|c|c|}
\hline & \multicolumn{2}{|c|}{$\begin{array}{l}\text { Exposed group } \\
(N=38)\end{array}$} & \multicolumn{2}{|c|}{$\begin{array}{l}\text { Reference group } \\
(N=20)\end{array}$} \\
\hline & Mean & Range & Mean & Range \\
\hline Age (years) & 38.7 & $19-63$ & 36.4 & $22-59$ \\
\hline Smokers (N) & 17 & & 8 & \\
\hline Exposure time (years) & 7.9 & $1-23$ & - & - \\
\hline $\begin{array}{l}\text { Time-weighted average } \\
\text { of the styrene leveis } \\
\text { in air in } 1980(\mathrm{ppm})\end{array}$ & 13 & $1-36$ & - & \\
\hline $\begin{array}{l}\text { Urinary mandelic acid } \\
\text { levels in } 1980 \\
\text { (mg/g creatinine) }\end{array}$ & 65 & $9-316$ & - & - \\
\hline $\begin{array}{l}\text { Micronuclei (\%o) } \\
\text { In hypotonically } \\
\text { treated cells } \\
\text { In cells with pre- } \\
\text { served cytoplasm }\end{array}$ & 4.3 & $0.5-18$ & 3.7 & $0-8$ \\
\hline $\begin{array}{l}72 \mathrm{~h} \\
96 \mathrm{~h} \\
\end{array}$ & $\begin{array}{l}3.9 \\
5.9\end{array}$ & $\begin{array}{l}0-12 \\
1-13\end{array}$ & $\begin{array}{l}3.0 \\
3.6\end{array}$ & $\begin{array}{l}0-14 \\
0-8\end{array}$ \\
\hline
\end{tabular}

heating of cobalt naphthenate or dimethyl aniline. The final styrene-modified polyester could be treated by drilling or grinding. It could also be glued by epoxy or polyurethane resins. Some of the products were degreased with methylene chloride and sprayed with paints containing different types of organic solvents. Large amounts of acetone were used for cleaning tools. Pressing tools, which were heated to $120^{\circ} \mathrm{C}$, were prepared with release agents contaminated with minute amounts of benzene.

Each subject was interviewed regarding occupational and medical history, especially concerning viral infections, use of alcohol and drugs, smoking habits, and exposure to ionizing radiation and heavy metals. Seventeen of the exposed subjects and eight of the referents were smokers (table 1).

Of the exposed subjects, 11 had had radiographic examinations during the last year, and 4 regularly took drugs (ibuprofen, hydrochlotiazid and atenolol, amitryptilin, and terbutalin). Five of the referents had been examined radiographically, and three had a regular drug intake (bendroflumethiazid, metoprolol, and antiallergic drugs).

One blood specimen and two urine samples (morning and afternoon) were obtained from each subject on either of two days (Tuesday or Wednesday).

Measurements of styrene in workroom air were made in close connection with the biological sampling.

Table 2. Styrene levels in the workroom air on different sampling occasions. Only the values from 1980 are 8-h time-weighted averages. In regard to dose estimations, see the section on individual styrene exposure.

\begin{tabular}{|c|c|c|c|c|c|c|c|c|c|c|c|c|}
\hline \multirow{3}{*}{$\begin{array}{l}\text { Type of } \\
\text { work }\end{array}$} & \multicolumn{12}{|c|}{ Styrene level (ppm) } \\
\hline & \multicolumn{2}{|c|}{1970} & \multicolumn{2}{|c|}{1975} & \multicolumn{2}{|c|}{1976} & \multicolumn{2}{|c|}{1977} & \multicolumn{2}{|c|}{1979} & \multicolumn{2}{|c|}{1980} \\
\hline & Mean & Range & Mean & Range & Mean & Range & Mean & Range & Mean & Range & Mean & Range \\
\hline \multicolumn{13}{|l|}{ Hand lay-up } \\
\hline 1 & 130 & $30-320$ & 44 & $7-93$ & 27 & $2-49$ & 21 & $17-24$ & 41 & $8-71$ & 16 & $15-16$ \\
\hline 2 & - & - & - & - & 34 & $24-60$ & - & - & 72 & $59-78$ & 13 & $7-19$ \\
\hline 3 & -- & - & - &.- & $-\cdots$ & - & - & - & - & - & 6 & $3-8$ \\
\hline Spray-up & - & - & 33 & $12-79$ & - & - & - & - & - & - & 9 & $7-13$ \\
\hline Pressing & - & - & - & - & - & - & - & - & - & - & 15 & $4-36$ \\
\hline \multirow{3}{*}{$\begin{array}{l}\text { Hot pressing of } \\
\text { sheet molding } \\
\text { compounds }\end{array}$} & - & - & 17 & $14-20$ & - & - & 31 & $1-78$ & - & - & 5 & $5-6$ \\
\hline & & & & & & & & & & & & \\
\hline & - & - & - & - & 14 & $2-24$ & - & - & - & - & 11 & $4-15$ \\
\hline $\begin{array}{l}\text { Total sampling } \\
\text { time (h) }\end{array}$ & 12 & & 64 & - & 44 & - & 31 & - & 66 & - & 307 & - \\
\hline
\end{tabular}


Micronuclei in lymphocytes with preserved cytoplasm

Five drops of whole blood were added to $5 \mathrm{ml}$ of McCoy's 5A medium with $20 \%$ newborn calf serum (Flow laboratories). Two cultures were set up for each person. After incubation with $0.135 \mathrm{ml}$ of phytohemagglutinin (Gibco) at $37^{\circ} \mathrm{C}$ for 72 and $96 \mathrm{~h}$ the cells were centrifuged, the medium was removed, and the cells were resuspended in an equal volume of medium, smeared on slides, air dried, and stained in May-Grünwald-Giemsa stain. The slides were coded and examined by one person with an oil immersion lens with a total magnification of $1,000 \times$.

The lymphocyte cytoplasm stained blue, and these cells could easily be differentiated from other nucleated cells with segmentation or fragmentation of the nucleus. The micronuclei were of different sizes but had to be smaller than one-third of the main nucleus and had to be clearly separated from it. They were of almost the same structure and color as the main nucleus.

Micronuclei in lymphocytes treated with hypotonic saline

The cells were cultured for $96 \mathrm{~h}$ by the same microculture technique as already described. Colchicin $(0.1 \mu \mathrm{g} / \mathrm{ml})$ was added $1 \mathrm{~h}$ before harvest since the preparations were also used for analyzing structural and numerical chromosome aberrations (Högstedt, to be published). Hypotonic treatment was carried out with potassium chloride $(0.075 \mathrm{~mol} / \mathrm{l})$ for $10-15 \mathrm{~min}$ at room temperature, and the cells were fixed four times in methanol:acetic acid $(3: 1)$. The cells were spread on slides, air dried, and stained in $2 \%$ Giemsa (Merck). The frequency of micronuclei was estimated from the scoring of 2,000 lymphocyte nuclei. Almost the same criteria as already given were used for the micronuclei. However, since the cytoplasm was lacking, the micronuclei had to be situated within two nuclear diameters of the main nucleus. The preparations were coded and examined by the same observer with the same magnification as was used for the cells with preserved cytoplasm.

\section{Air styrene determinations}

The workroom air concentrations of styrene were determined for all types of work in close connection with the blood sampling in 1980. Altogether, 262 air samples were collected by stationary and personal sampling with a total sampling time of $307 \mathrm{~h}$. The samples were analyzed either by an infrared spectrophotometric or a gas chromatographic method. The detection limit was below $1 \mathrm{ppm}$. Measurements had been done previously with a combustible gas indicator and reagent tubes (in 1970) and gas chromatographic methods (in 1975, 1976, 1977, and 1979). The levels found for the individuals in the study on different sampling occasions are shown in table 2. The measurements in 1970-1979 were performed during short times and only in spots where high exposure levels were expected. Only the results from 1980 are time-weighted averages for $8 \mathrm{~h}$ of exposure, and they refer directly to the individuals in the present study.

\section{Mandelic acid in urine}

Urine samples were obtained in the afternoon after $6 \mathrm{~h}$ of work (Tuesday and Wednesday) and on the following morning immediately after the subject awakened. Mandelic acid was determined by a highpressure liquid chromatography method (10). The limit of detection was $5 \mathrm{mg} / \mathrm{l}$. The accuracy was checked by interlaboratory comparison. The levels of mandelic acid were related to the urinary creatinine levels (13).

\section{Relationship between styrene in air and mandelic acid in the urine}

There was a statistically significant correlation between the measurements of mandelic acid in the afternoon and morning urine $(\mathrm{r}=0.73, \mathrm{~N}=37, \mathrm{p}=0.002)$ and between these measurements and the levels of styrene in the workroom air at the time of the investigation $(\mathrm{r}=0.64, \mathrm{~N}=37$, $\mathrm{p}=0.002$, and $\mathrm{r}=0.41, \mathrm{~N}=37, \mathrm{p}=0.012$, respectively).

\section{Individual styrene exposure}

For each worker approximate concentrations of styrene in the workroom air during 
the period 1970-1980 were estimated on the basis of occupational history and styrene levels in the plant. Thus we calculated the mean concentrations of the last one, three and ten years, as well as the accumulated doses (parts per million $\times$ years) during the last three and ten years. During the last five years no one in this study had an exposure level exceeding a timeweighted average of $40 \mathrm{ppm}$. The mean time-weighted average level in the last year (1980) was $13 \mathrm{ppm}$ (range 1-36 ppm) (table 2).

\section{Statistical analysis}

To evaluate the effects of styrene exposure, smoking, and age on the cytogenetic variables, a multivariate analysis was performed (5). Since this type of analysis demands normal distribution of the variables, the values were transformed into logarithms to meet approximately this requirement.

The styrene-exposed group of individuals was divided into two groups. The first had been working not more than five years $(\mathrm{N}=16)$ and thus had not been exposed to styrene levels exceeding a time-weighted average of $40 \mathrm{ppm}$. The second consisted of persons who had been exposed for more than five years $(\mathrm{N}=22)$.

The effect of exposure was also tested with the use of the different individual dose estimates mentioned in the section on individual styrene exposure, the values of mandelic acid in the morning and the afternoon urine samples, and the time of employment.

In the analysis of correlation the Spearman rank correlation coefficient was used (12). The statistical significance level used was $\mathrm{p}<0.05$. All tests were two-sided.

\section{Results}

There was a significant effect of styrene exposure on micronuclei in lymphocytes with preserved cytoplasm cultured for $96 \mathrm{~h}$ $(p=0.005)$ (table 1 , fig 1$)$ when other potentially influencing factors such as smoking and age were eliminated in the multivariate analysis. Even in individuals who had been working for only five years or less ( $\mathrm{N}=$ 16) and thus had never been exposed to styrene levels exceeding a time-weighted average of $40 \mathrm{ppm}$, there was a difference between the exposed and the reference group (means 6.3 vs $3.6 \%, \mathrm{p}=0.028$ ).

In lymphocytes with preserved cytoplasm cultured for $72 \mathrm{~h}$ and in hypotonically treated cells the increase of micronuclei was not statistically significant (table 1 , fig 1 ).

In the study of dose-response relationships between styrene exposure and micronuclei, the effects of the different individual dose estimates were analyzed separately for the exposure group. No such relationships were found between the different dose estimates, ie, exposure time, individual styrene air levels (during the last one, three, and ten years), the individual accumulated doses (parts per

FREQUENCY OF

MICRONUCLEI $(\% \circ)$

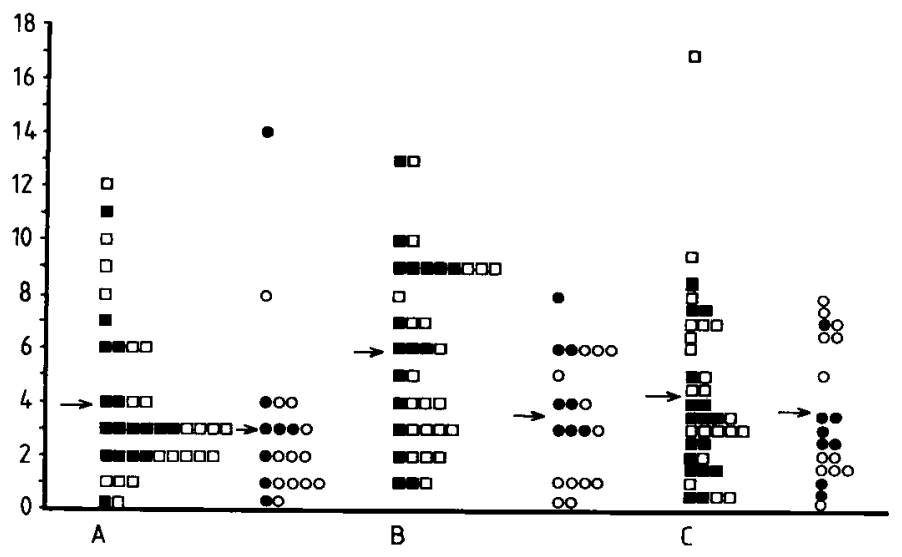

Fig 1. Frequency of micronuclei. $(A=$ micronuclei in lymphocytes with preserved cytoplasm cultured for $72 \mathrm{~h}, \mathrm{~B}=$ micronuclei in lymphocytes with preserved cytoplasm cultured for $96 \mathrm{~h}, \mathrm{C}=$ micronuclei in hypotonically treated lymphocytes cultured for $96 \mathrm{~h}$, closed squares = styreneexposed smokers, open squares = styrene-exposed nonsmokers, closed circles = nonexposed smokers, open circles = nonexposed nonsmokers) 
million $\times$ years in the last three and ten years), or urinary mandelic acid levels (in the morning or afternoon) on one hand and the frequencies of micronuclei on the other.

\section{Discussion}

The main result of this investigation was the increase of micronuclei in lymphocytes with preserved cytoplasm after low exposure to styrene. Smoking and age, which were allowed for in the statistical analysis, also had significant effects on the frequencies of micronuclei (Högstedt, to be published). We have earlier shown an increased level of carcinogen-induced unscheduled deoxyribonucleic acid synthesis in blood specimens collected at the same time from the same group of individuals (11).

The present exposure level (a mean of 13 ppm during the last year) associated with cytogenetic effect is lower than in any published study of structural chromosome aberrations among styrene-exposed workers. The accuracy of the estimates of recent exposure is supported by low and correlated levels of styrene in the air and mandelic acid in the urine. The estimates of earlier exposure are probably not as accurate. However the information is sufficient to conclude that the mean exposure level did not exceed $40 \mathrm{ppm}$ for any individual during the last five years. In addition those individuals who had been working in the factory for less than five years showed a statistically significant effect for styrene.

No dose-response relationship was found in this study between different individual dose estimates of styrene and micronuclei in lymphocytes. This lack of relationship was not surprising, as the dose range was rather narrow. In addition there was a lack of precision in the individual dose estimates of the earlier years. Furthermore the effect might have been caused by a confounding factor in the work environment. Thus there were several chemical compounds with potential mutagenic activity (see the Material and Methods section). It must be stressed however that styrene, because of its high vapor pressure, was the main pollutant in the workroom air. The hygienic standard for styrene in Sweden has recently been reduced to $25 \mathrm{ppm}$. Our results suggest that, from an international point of view, not even this very low level will supply full protection against cytogenetic damage.

The present results are consistent with another study on the effect of low styrene levels (Nordenson, personal communication) which revealed an increase of micronuclei in lymphocytes with preserved cytoplasm and an increase of cells with aneuploidy but not an increase of structural chromosome aberrations. Our results, together with those of Nordenson, may suggest that exposure to styrene at a low level preferably causes disturbances of the spindle apparatus, but not necessarily chromosome breakage.

\section{Acknowledgments}

We thank Mr L-O Andersson for his valuable help with practical aspects of this investigation. G Malmberg, MSc(Eng), contributed with chemical and technical viewpoints on the polyester production.

The investigation was supported by grants from the Swedish Work Environment Fund (ASF 80/403) and the Swedish Cancer Society.

\section{References}

1. Andersson HC, Tranberg EÅ, Uggla AH, Zetterberg G. Chromosomal aberrations and sister chromatid exchanges in lymphocytes of men occupationally exposed to styrene in a plastic boat factory. Mutat res 73 (1980) 387-401.

2. Countryman PJ, Heddle JA. The production of micronuclei from chromosome aberrations in irradiated cultures of human lymphocytes. Mutat res 67 (1976) $321-332$.

3. Fleig I, Thiess AM. Mutagenicity study of workers employed in the styrene and polystyrene processing and manufacturing industry. Scand $j$ work environ health 4 (1978): suppl 2, 254-258.

4. Högstedt $\mathrm{B}$, Hedner $\mathrm{K}$, Mark-Vendel $\mathrm{E}$, Mitelman F, Schütz A, Skerfving S. Increased frequency of chromosome aberrations in workers exposed to styrene. Scand $\mathbf{j}$ work environ health 5 (1979) 333-335.

5. Lindman HR. Analysis of variance in complex experimental designs. WH Freeman \& Co, San Francisco, CA 1974.

6. Linnainmaa $\mathrm{K}$, Meretoja $\mathrm{T}$, Sorsa $\mathrm{M}$, Vainio $H$. Cytogenetic effects of styrene and styrene oxide in human lymphocytes 
and Allium cepa. Scand j work environ health 4 (1978): suppl 2, 156-162.

7. Meretoja T, Vainio H, Sorsa M, Härkönen $H$. Occupational styrene exposure and chromosomal aberrations. Mutat res 56 (1977) 193-197.

8. Norman A, Adams FH, Riley RE. Cytogenetic effects of contrast media and triiodobenzoic acid derivatives in human lymphocytes. Radiology 129 (1978) 199-203.

9. Norppa H. Chromosome damage induced by styrene, styrene oxide and some analogues. Doctoral dissertation. University of Helsinki, Helsinki 1981.

10. Ogata M, Sugihara R. High performance liquid chromatographic procedure for quantitative determination of urinary phenyl glyoxylic, mandelic, and hippuric acids as indices of styrene exposure. Int arch occup environ health 42 (1978) 11-19.

11. Pero RW, Bryngelsson $T$, Högstedt $B$, Ákesson B. Occupational and in vitro exposure to styrene assessed by unscheduled DNA synthesis in resting human lymphocytes. Carcinogenesis 3 (1982) 681-685.

12. Siegel $S$. Nonparametric statistics for the behavioral sciences. McGraw-Hill, Kogakusha 1956, pp 203-213.

13. Teger-Nilsson AC. Serum creatinine determinations using an ion exchange resin. Scand $\mathbf{j}$ clin lab invest 13 (1961) $223-331$

Received for publication: 2 February 1983 